\title{
Corporate Governance and Agency: The Nigerian Banking Sector
} Experience

\author{
Adeyemi Babalola \\ Department of Accounting and Finance Ajayi Crowther University, P.M. B, 1066, Oyo, Oyo State, Nigeria \\ babalolaadeyemi@yahoo.com
}

\begin{abstract}
Corporate governance has ignited heightened interest with the collapse of key companies round the world. The demise of Enron, Arthur Anderson, Health Smith and others took the entire globe by surprise. All the stakeholders are now very interested in setting standards and enacting laws that address current issues to protect unsuspecting investors. In this regard, the United States Congress enacted the Sarbanes-Oxley Act of 2002 to guide the practice of corporate governance particularly in the public corporation of the country. This paper thus examined the issue of agency as it relates to corporate governance. It attempted to determine the extent to which the directors and management of banks are in congruent with this role. It also assessed the impact of agency on corporate governance in the Nigerian banking sector. In carrying out this study simple percentages through the aid of frequency distribution were used to describe the data collected. T-test statistic was employed to analyse the data. and in conclusion, the study was of the view that agency impacts negatively on corporate governance practices in Nigeria. The study therefore recommended that the banking sector should endeavour to entrench effective corporate governance that will compel the directors and the management to be truly and genuinely accountable to the stakeholders. It also recommended that the Central Bank of Nigeria should strengthen its enforcement mechanisms such that there will be total transparency and full disclosure of all material transactions to the stakeholders and the regulatory authorities.
\end{abstract}

Keywords: Corporate Governance, Agency, Banking Sector, Directors, Transparency, Disclosure Stakeholders, Management

\section{Introduction}

Anameje (2007) asserts that the subject of corporate governance has of recent, assumed a global significance having been found to be crucial for sustainable corporate performance. The incredible collapse of a number of corporate giants which were believed to be the front-liners in business performance has brought to the fore the need for greater transparency and accountability in corporate management. It is instructive to note that there is hardly any sector of the Nigerian economy that has not suffered the consequences of lack of good corporate governance practice. This is underscored by the on-going efforts of the Federal Government of Nigeria at entrenching accountability and transparency in both the public and private sectors of the economy. Sanusi (2004) observes that "we have witnessed the collapse of many public corporations as well as private business organizations and the attendant negative implications for economic growth and development". Such perverse consequences tend to become extremely worrisome when one realizes that the banking sector has been the worst hit especially since the 1990s.

The issue of agency has played a paramount role in corporate governance. The management and the board of directors of companies are agents whose role is to act in the best interest of the stakeholders. Unfortunately, the objectives of these agents are often at variance with those of the firms' stockholders as well as those of the other stakeholders. Van Horne (2002) opines that in a large corporation, the stock may be so widely held that stockholders cannot even make known their objectives, much less control or influence management. Often, ownership and control are separate, a situation that allows management to act in its own best interest rather than those of its stockholders. In a bid to forestall the greed and the selfish interest, of the management, a good number of the privately-owned banks had the ownership and management concentrated, in most cases, in a single hand, representing the interest of the family controlled banks.

Agency problem has therefore become another challenging area in corporate governance in the Nigerian banking sector which requires a serious attention otherwise, with the total separation of ownership from management as demanded by the latest Banking Sector Reforms, the agents, who are the management and the board, may continue to take undue advantage of the innocent stakeholders. Rather than maximizing the wealth of the stockholders and protecting the interest of the entire stakeholders, the agents will pursue their own objectives instead. 


\subsection{Statement of the Problem}

Corporate governance structures in banks rest solely on three principal actors: the board of directors, management and the shareholders. The directors and the senior management act as agents in the running of the company and are accountable to the shareholders. While Sanusi (2002) contends that the board should ensure that the bank is run with integrity, complies with all legal requirements and regulatory standard and conduct its business in accordance with high ethical standard, Diplock (2004),opines that for a board to function effectively, it should be composed of members who are independent, skilled, knowledgeable, experienced and of diverse perspectives. Adedipe (2004) on the other hand, is of the view that ownership must be separated from the day to day running of the firm.

The agency theory however is of the position that in the presence of information asymmetry, the agent who may be a director or a manager is likely to pursue interests that may hurt the principal or share-holders (Ross, 1973; Fama, 1980). The owners had imperfect information concerning the opportunities facing managers and could not by looking at outcomes, infer, whether or not, managers had made the decisions (Shleifer and Vishny, 1997).

Jensen and Meckling (1976), focus on the contract of an agency relationship between the principal and the agent. They demonstrate that as the owner's manager's fraction of the equity falls, the utility maximizing agent has the incentive to appropriate a large amount of the corporations' resources in the form of perquisites and to exert less than full efforts to create value for shareholders. Akinsulire (2002) observes that in larger companies, ordinary shares are likely going to be diversely held and so the actions of shareholders are likely going to be restricted in practical terms. The management of an organization is essentially agents for the shareholders, being tasked with running the organization in the shareholders' best interests. The shareholders however have little opportunity to assess whether the managers are acting in the shareholders' best interests.

There is a serious absence of financial disclosure which would have strengthened the accountability of directors and senior management and enhance the incentives for risk management. To worsen the situation, Oluyemi (2005) observes that there is a huge non-performing loans attributable to the directors of the banks. This would have been made possible as a result of the directors and management embarking on the pursuit of their selfish interest which is to the detriment of the stakeholders. Because the agents are seen as not acting in the best interest of the stockholders the tenets of good corporate governance and agency are often difficult to preserve.

\subsection{Objectives of the Study:}

(i) To examine the issue of agency in corporate governance within the Nigerian banking sector

(ii) To determine the extent to which the directors and management of banks carry out this role

(iii) To explore the significant relationship between corporate governance and agency

\section{Conceptual Framework and Literature Review}

According to Mulbert (2009), a generally accepted definition of corporate governance has not yet evolved. Traditional concepts describe corporate governance as a complex set of constraints that shape the ex post bargaining over the quasi-rents generated by a firm or as every device, institution or mechanism that exercises power over decision making within a firm (Zingales, 2008 and Macey 2008). Put differently, corporate governance deals with the decision- making at the level of the board of directors and top management (i.e., the management board in a two-tier system), and the different internal and external mechanisms that ensure that all decisions taken by the directors and top management are in line with the objectives(s) of a company and its shareholders respectively.

The most widely accepted definition of corporate governance embodied in the OECD principles of Corporate Governance and referred to in the European Commission's Action Plan on Company Law and Corporate Governance takes a slightly broader view: "Corporate governance involves a set of relationships between a company's management, its board, its shareholders and other stakeholders". Corporate governance also provides the structure through which the objectives of the company are set, and the means of attaining those objectives and monitoring performance are determined. Good corporate governance should provide proper incentives for the board and management to pursue objectives that are in the interests of the company and its shareholders, and should facilitate effective monitoring. This definition goes beyond the definitions cited above mainly insofar as a company's objectives(s) and the mechanism for setting the objective(s) are treated as a corporate governance issue, not as endogenously given. 
By contrast, a much broader definition describes corporate governance as encompassing the standards for decision-making within a company, the duties of board members and officers, the internal structure of the firm (enterprise) and the relationship between the corporation and its shareholders and other stakeholders. Such a concept of corporate governance goes beyond even the OECD's definition in two respects: first, by implying that corporate governance also deals with substantive management issues and the pertinent decision-making by the board and top management, for example, by requiring them to set up an independent compliance function and a risk-management system, and second, by dealing with the internal structure of the firm, i,e. with internal structures below the level of the company's board and officers (top management).

Monks and Minow (1995) state that corporate governance is the relationship among various participants in determining the direction and performance of corporations. Tricker (1994), opines that "corporate governance addresses the issues facing the board of directors, such as the interaction with top management, and the relationship with the owners and other interested parties in the affairs of the company including creditors, debt financiers, analysts, auditors and corporate regulators". 'Shleifer and Vishny (1997) define corporate governance by stating that' it deals with the ways in which suppliers of finance to corporations assure themselves of getting a return on their investment. A similar concept is suggested by Caramanolis-Cotelli (1995) who regards corporate governance as being determined by the equity allocations among insiders (including executives, chief executive officers (CEO's), directors or others individuals (corporate or institutional investors who are affiliated with management) and outside investors.

Owoh (2006) observes that corporate governance is concerned with a clear distinction between the top management's operational processes, and the highest-level policy-based structure of an organization. The governance structure formulates policies and gives general road-map for the organization, while the top management breaks down these polices into implementable bits and follows-through same in the course of its daily operations. John and Senbet (1998) propose a more comprehensive definition that "corporate governance deals with mechanisms by which stakeholders of a corporation exercise control over corporate insider and management such that their interests are protected". They include as stakeholders, not just share holders, but also debt holders and even non-financial stakeholders such as employees, customers and other interested parties.

The Basel Committee on Banking Supervision states that "corporate governance involves the manner in which the business and affairs of banks are governed by their board of directors and senior management which affects how they:

set corporate objectives

operate the banks' business on a day-to-day basis

meet the obligations of accountability to their shareholders and take into account, the interest of other stakeholders

align corporate objectives and behaviour with the expectation that banks will operate in a safe and sound manner and in compliance with applicable laws and regulations;

protect the interest of depositors".

The existing literatures in some key areas of corporate governance are reviewed with a view to considering their strength and short comings. The areas considered are board of directors, board responsibilities, separation of chairman from chief executive officer, high quality financial disclosure and huge non- performing loans.

Board of Directors: According to Kumar and Singh (2010), the primary role of the board of directors is that of trusteeship to protect and enhance shareholders' value though strategic supervision. As trustees they will ensure that the company has clear goals relating to shareholders' value and its growth. They should set strategic goals and seek accountability for their fulfillment. They will provide direction, and exercise appropriate control to ensure that the company is managed in a manner that fulfills stakeholders' aspirations and societal expectations. The board must periodically review its own functioning to ensure that it is fulfilling its role.

There must be a balanced board, consisting of executive and non-executive directors, the latter including independent professionals. The executive directors, including the executive chairman, shall not generally exceed $1 / 3^{\text {rd }}$ of the total strength of the board. The non-executive directors shall comprise eminent professionals drawn from amongst persons with experience in business/ finance/ law/ public enterprises. The directors shall be appointed/re-appointed for a period of three to five years, and in the case of executive directors up to the date of their retirement, whichever is earlier. The board shall determine from time to time the retirement age for both executive and non-executive and non-executive directors. The board shall specify the maximum number of company directorships which can be held by members of the board (Kumar and Singh 2010). The non-executive 
directors are however expected to play a critical role in imparting balance to the board processes by bringing an independent judgment to bear on issues of strategy, performance, resources, standard of company conduct, etc.

Board Responsibilities: Sanusi (2002) contends that the governance of banks rest with the board of directors. For this reason the board should ensure that the bank is run with integrity, complies with all legal requirements and regulatory standard and conduct its business in accordance with high ethical standard. Diplock (2004) opines that effective corporate governance is all about board's performance. The task of governing a corporate entity is the work of board of directors. For a board to function effectively, it should be composed of members who are independent, skilled, knowledgeable, experienced and of diverse perspectives. Chukwudire (2004) contends that Nigeria has had high profile cases of corporate failure which are traceable to weak and ineffective boards. In some cases, the board appears to have been dormant. Members of such boards are satisfied with having business cards that identify them as board members. In a number of cases, the boards become a part of management rather than an active monitor of its performance.

High Quality Financial Disclosure: Cheserem,, Bowes, Garratt, Gillibrand, Jayamaha, Laferla, Mortlock \& Reddy (2000) observe that an essential complement to sound corporate governance is the implementation of robust financial disclosure requirements for corporate and financial institutions. Financial disclosure is essential as a means of strengthening the accountability of directors and senior management and enhancing the incentives for risk management. It is also essential if market participants and observers - particularly the larger creditors of banks, financial news media, financial analysts and rating agencies - are to effectively monitor the performance and soundness of financial institutions and exercise appropriate disciplines on those institutions which do not perform well or fail to meet acceptable prudential standards. Financial disclosure is also essential if smaller creditors, including depositors of banks, are to have any chance of protecting their own interests, particularly in the absence of deposit insurance.

Huge Non-Performing Loans A major revelation showed that many owners and directors abused or misused their privileged positions or breached their fiduciary duties by engaging in self serving activities. The abuses included granting of unsecured credit facilities to owners, directors and related companies which in some cases were in excess of their banks' statutory lending limits, in violation of the provisions of the law (Oluyemi, 2005).

\subsection{Theoretical Framework}

Agency Theory: This theory is of the position that in the presence of information asymmetry, the agent who may be a director or a manager is likely to pursue interests that may hurt the principal or share-holders (Ross, 1973; Fama, 1980). At first the theory was applied to the relationship between managers and equity holders with no explicit recognition of other parties interested in the well-being of the firm. This owner/manager theory views shareholders as the true owner of the firm. Thus, bondholders and other lenders, workers and local authorities have no real say in the actions of the firm even though they have rights to certain flow of income. Workers have the right to be paid wages and local authorities have rights to be paid taxes due hence the residual claimants with respect to both control and income and the shareholders. The owners had imperfect information concerning the opportunities facing managers and could not by looking at outcomes; infer whether or not managers had made the decisions. The imperfection of information necessitated the delegation of responsibilities to managers as managers not only knew this but could take actions that exacerbated the asymmetries of information enhancing managers' discretionary authority (Shleifer and Vishny, 1997).

In analyzing the agency problem, Jensen and Meckling (1976), develop a theory of the ownership structure of a firm. The basis for their analysis is the perspective that a corporation is "a legal fiction which serves as a nexus for contracting relationships and which is also characterized by the existence of divisible residual claims on the assets and cash flows of the organization which can generally be sold without the permission of the other contracting individuals". The particular focus on this model is the contract of an agency relationship between a principal (the external owner of the firm) and an agent (the owner-managers, or entrepreneur). They demonstrate that as the owner's manager's fraction of the equity falls (as more equity is sold to outside investors), the utility maximizing agent has the incentive to appropriate a large amount of the corporations' resources in the form of perquisites and to exert less than full efforts to create value for shareholders.

According to Peterson (2010), agency theory explains, predicts, and sets the limits of relationships between financial parties. Theoretically, desired executive performance is assured in exchange for compensation when he meets the needs of his/her organization as a financial steward. When the executive chooses to manipulate the financial results through managerial activity and that activity maximizes the return to the executive rather than financial return to an organization in the form of return on investment or equity we say there is an agency 
problem. Preston (2010) also observes that in the case of agency theory, much of this voluminous literature relates to how management, as agent of shareholders, align their interests with those of the company through tools (for instance salaries, options, contracts, and bonus plans) created by boards of directors when there is limited information and a bounding of rationality in the judgment process. In this regard, agency theory can be used to explain some of the behavior between them. The essential emphasis is that agency is characterized by the risk attitudes of principals and agents. According to Eisenhardt (1989) where principals are considered risk neutral in their preferences for individual firm actions, since they can diversify their holdings across multiple business opportunities. They use agents, managers, to carry out their plans, using control tools like employment security as an agent, income, bonus, or contract. In the absence of (or to enhance) these tools, the literature also suggests that a trust relationship can be established that can lower agency costs and establish another agency tool that predicts performance.

Agents, on the other hand, are assumed to be risk averse (Meyer, et al, 1995), They want to lower risk to their personal wealth, and will work to complete goals in order to not endanger outcomes. This risk differential between agents and principals creates a moral hazard problem between agency in the principal agent relationship where agents are faced with a wide range of goals and incentives that may or may not be in the true interests of the firm, but rather are perceived to be so (or may not be at all, e.g. Enron) by the board. The challenge of corporate governance is to shore up supervisory and alignment mechanisms that alter the risk orientation of agents to align them with the interests of principals, However, Peterson (2010) further observes that agency dilemmas exist when there is more than one principal conducting business with one agent. The conflict of interest resulting from multiple objectives provided by many principals results in the desire to complete all objectives, but result in the partial accomplishment of some.

Fiduciary Duties: Macey and O'Hara (2003) opines that on a theoretical level, the problems of corporate governance result from the existence of incomplete contracts. The rules of corporate governance are aimed at resolving the gaps left in these contracts in ways consistent with maximizing the value of the firm. In the case of shareholders' contingent contracts in the United States, the background rules are called fiduciary duties. The economic justification for having fiduciary duties is straightforward: "Fiduciary duties are the mechanism invented by the legal system for filling in the unspecified term of shareholders' contingent (contracts).," the creation of a contract covering all possible contingencies is impossible between shareholders and boards of directors. Relying only on an incomplete contract to define the relationship between shareholders and directors would lead to unacceptably high monitoring cost on both sides the presence of fiduciary duties attempts to address these contingencies. In this gap-filling role, fiduciary duties essentially call on directors to work hard and to promote the interest of shareholders above their own. They argue that, to the extent that fiduciary duties lower agency cost by reducing the freedom of management to act in its own unconstrained self-interest, such duties will be especially valuable devices in the banking context because of the inherent difficulties in monitoring banks.

Akinsulire (2002) opines that a possible conflict can arise when ownership is separated from the day to day management of an organization. In larger companies, ordinary shares are likely going to be diversely held and so the actions of shareholders are likely going to be restricted in practical terms. The responsibility of running the company will be with the board of directors who may only own a small percentage of the shares in issue. The management of an organization is essentially agents for the shareholders, being tasked with running the organization in the shareholders best interests. The shareholders however have little opportunity to assess whether the managers are acting in the shareholders' best interests.

According to Van Horne (2002), we may think of management as agents of the owners. Stockholders, hoping that the agents will act in the stockholders' best interest, delegate decision making authority to them. Jensen and Meckling were indeed the first to develop a comprehensive agency theory of the firm. They show that the principals, in our case, the stockholders, can assure themselves that the agent (management) will make optimal decisions only if appropriate incentives are given and only if the agent is monitored. Monitoring, however, can be done by bonding the agent, systematically reviewing management perquisites, auditing financial statements and explicitly limiting management decisions Thus, the existing evidences on corporate governance strongly suggest that some managerial actions are inconsistent with the maximization of shareholders' interest and those of the stakeholders'. Hence, there is the possibility of people behaving both as opportunistic, self serving agents and selfless stewards.

There is no theory/model of society that is likely to be sufficient for understanding, evaluating or designing governance structures. The reliance on just one theory or one perspective may unlikely be rewarding in practical 
terms for corporate governance system. Nevertheless, this study is hinged on the agency theory which tends to suggest that the objectives of the management may differ from those of the firm's stockholders. While the management pursue their own personal interest, which may be detrimental to the interest of the shareholders, the latter expects the former to act as loyal and faithful agents.

\section{Methodology}

The source of data collection for the research work was primary in nature. The study made use of structured questionnaire as its research design. The study population covers the entire banking sector but the sample size was limited to 5 selected banks headquartered in Lagos. A total of 80 staff (16 staff from each of the 5 banks) were selected randomly and these were basically head office staff. The 5 banks were also selected at random and the 5 banks were Stanbic IBTC Bank Plc, United Bank for Africa Plc and Access Bank Plc representing 15 healthy banks declared by the Central Bank of Nigeria and accounting for $20 \%$ of the banks in this category. The other two were Bank PHB Plc. and Afribank Plc representing the 9 troubled banks and accounting for approximately $20 \%$ as well. Out of the 80 questionnaire administered to respondents, 72 or $(90 \%)$ were duly filled and returned. In addition to the primary sources, secondary sources were also utilised. Academic journals, textbooks, research papers and other materials that were considered useful for the study were consulted. For the purpose of this study therefore, a major hypothesis was formulated and this is as stated underneath:

Ho: There is no significant relationship between agency and poor corporate governance

\section{Data Presentation and Analysis}

This study was designed to ascertain the degree of association between poor corporate governance and agency. The section focuses essentially on the presentation, analysis and interpretation of the primary data collected using a well-structured questionnaire. Statistical Package for Social Sciences was used to analyze the collected primary data. In all, the researcher distributed a total of 80 copies of questionnaire to the employees of five different banks listed above at their headquarters and within the Lagos environment, out of which 72 were duly filled and returned. The response rate is as shown in the table below

\section{Section A}

Table 1: Respondents Rate of Return

\begin{tabular}{|l|c|c|c|}
\hline & Frequency & Percentage & Cumulative Percentage \\
\hline Returned & 72 & 90 & 90.0 \\
\hline Not Returned & 8 & 10 & 100.0 \\
\hline Total & 80 & 100.0 & \\
\hline
\end{tabular}

Source: Field Survey, 2012

Table 1 above revealed that (72) or $90 \%$ of the respondents filled and returned the questionnaire administered on them while (8) or $10 \%$ did not return their own questionnaire

Table 2: Sex

\begin{tabular}{|l|c|c|c|}
\hline & Frequency & Percentage & Cumulative Percentage \\
\hline Male & 42 & 58.33 & 58.33 \\
\hline Female & 30 & 41.67 & 100.0 \\
\hline Total & 72 & 100.0 & \\
\hline
\end{tabular}

Source: Field Survey, 2012

Table 2 shows that (42) or $58.33 \%$ of the respondents are male while (30) or $41.67 \%$ are female. 
Table 3: Age

\begin{tabular}{|l|c|c|c|}
\hline & Frequency & Percentage & Cumulative Percentage \\
\hline 21 - 30years & 36 & 50.0 & 50.0 \\
\hline $31-40$ years & 24 & 33.33 & 83.33 \\
\hline $41-50$ years & 12 & 16.67 & 100.0 \\
\hline Total & 72 & 100.0 & \\
\hline
\end{tabular}

Source: Field Survey, 2012

Table 3 shows that (36) or 50\% of the respondents are between the ages of $21-30$, (24) or $33.33 \%$ are between 31- 40 years, while (12) or $16.67 \%$ of the respondents are between the ages of 41 years to 50 . Thus, majority of the respondents are young and are expected to be dynamic in their thinking and approach to issues.

Table 4: Marital Status

\begin{tabular}{|l|c|c|c|}
\hline & Frequency & Percentage & Cumulative Percentage \\
\hline Single & 24 & 33.33 & 33.33 \\
\hline Married & 42 & 58.33 & 91.66 \\
\hline Widow/Divorcee & 6 & 8.34 & 100.0 \\
\hline Total & 72 & 100.0 & \\
\hline
\end{tabular}

Source: Field Survey, 2012

Table 4 above revealed that (24) or $33.33 \%$ were single, (42) or 58.33 were married while only (6) or $8.34 \%$ were either widow /widower or divorcee. Thus majority or about $92 \%$ of the respondents are either married or single

Table 5: Work Status

\begin{tabular}{|l|c|c|c|}
\hline & Frequency & Percentage & Cumulative Percentage \\
\hline Top Management & 18 & 25.0 & 25.0 \\
\hline Middle Management & 36 & 50.0 & 75.0 \\
\hline Junior Staff & 18 & 25.0 & 100.0 \\
\hline Total & 72 & 100.0 & \\
\hline
\end{tabular}

Source: Field Survey, 2012

Table 5 shows that (18) or $25 \%$ of respondents are top management, (36) or $50 . \%$ of the respondents are middle management staff (18) or $25 . \%$ of the respondents are junior staff. Thus, the survey revealed that most of the respondents are from the top management or middle level management cadre. 
Table 6: Work Experience

\begin{tabular}{|l|c|c|c|}
\hline & Frequency & Percentage & Cumulative Percentage \\
\hline Below 10 years & 20 & 27.78 & 27.78 \\
\hline 11- 20years & 24 & 33.33 & 61.11 \\
\hline 21- 30years & 16 & 22.22 & 100.0 \\
\hline 31years and above & 12 & 16.67 & \\
\hline Total & 72 & 100.0 & \\
\hline
\end{tabular}

Source: Field Survey, 2012

Table 6 shows that (20) or $27.78 \%$ of the respondents had experience of less than 10years, (24) or 33.33\% had between 11 and 20 years, (16) or $22.22 \%$ fall between 21 and 30 years experience while (12) or $16.67 \%$ had experience of 31 years and above

\section{Section B}

For the purpose of this write-up only a few of the most relevant items in the structured questionnaire are picked and stated below:

Table 7: Agency role precipitates poor corporate governance

\begin{tabular}{|l|c|c|c|}
\hline & Frequency & Percentage & Cumulative Percentage \\
\hline Yes & 69 & 95.83 & 95.83 \\
\hline No & 2 & 278 & 98.61 \\
\hline Not Sure & 1 & 1.39 & 100.0 \\
\hline Total & 72 & 100.0 & \\
\hline
\end{tabular}

Source: Field Survey, 2012

From Table 7 above, (69) or $95.83 \%$ of the respondents agreed that agency role could precipitate poor corporate governance. Thus, majority of the respondents agree with this view.

Table 8: There is a significant relationship between agency and poor corporate governance

\begin{tabular}{|l|c|c|c|}
\hline & Frequency & Percentage & E Cumulative Percentage \\
\hline Strongly Agree & 18 & 25.0 & 25 \\
\hline Agree & 46 & 63.89 & 88.89 \\
\hline Not Sure & 2 & 2.78 & 91.67 \\
\hline Disagree & 5 & 6.94 & 98.61 \\
\hline Strongly Disagree & 1 & $1.39-$ & 100.0 \\
\hline Total & 72 & 100 '0 & - \\
\hline
\end{tabular}

Source: Field Survey, 2012

The table revealed that (18) or $25 \%$ of the respondents strongly agreed that there is a correlation between poor corporate governance and agency, (46) or $63.89 \%$ agreed with this viewpoint. About $2.78 \%$ were not sure while $6.94 \%$ disagreed with the view. It can be inferred therefore that there is a correlation between poor corporate governance and agency. 
Table 9: Agency impacts negatively on corporate governance

\begin{tabular}{|l|c|c|c|}
\hline & Frequency & Percentage & E Cumulative Percentage \\
\hline Strongly Agree & 36 & 50.0 & 50 \\
\hline Agree & 18 & 25.0 & 75 \\
\hline Not Sure & 9 & 12.50 & 87.50 \\
\hline Disagree & 5 & 6.94 & 94.44 \\
\hline Strongly Disagree & 4 & 5.56 & 100.0 \\
\hline Total & 72 & $100 ’ 0$ & - \\
\hline
\end{tabular}

Source: Field Survey, 2012

From the table above, (36) or 50\% strongly agreed that agency impacts negatively on corporate governance, (18) or $25 \%$ also agreed with this view point. Thus, majority of the respondents are of the opinion that agency impacts negatively on corporate governance

\section{Testing of Hypothesis}

The hypothesis for this study is tested using both the student's t-test. The results obtained from this test is as shown and discussed below.

Table 10: One-Sample Statistics

\begin{tabular}{|l|c|c|c|c|}
\hline & Mean & $\begin{array}{c}\text { Standard } \\
\text { Deviations }\end{array}$ & $\begin{array}{c}\text { Standard } \\
\text { Error Mean }\end{array}$ \\
\hline $\begin{array}{l}\text { There is a significant relationship } \\
\text { between agency and poor corporate } \\
\text { governance }\end{array}$ & 72 & $\mathbf{2 . 0 1}$ & .986 & .116 \\
\hline
\end{tabular}

Comment: Using the 5 point Likert scale, 1 represents strongly agree, 2 represents agree, 3 represents not sure, 4 represents disagree and 5 represents strongly disagree, the mean of 2.01 shows that the average response indicates that the respondents agree that there is a significant relationship between agency and poor corporate governance

\section{Table 11: One-Simple Test}

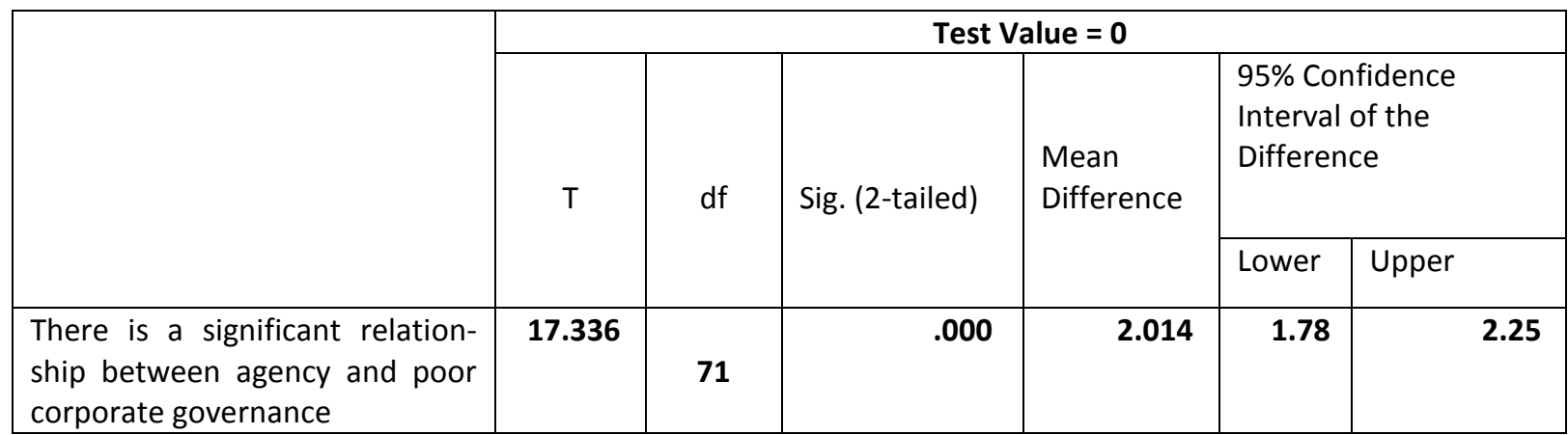

Comment: The table above shows a two-tailed test with degree of freedom (d.f) $72-1=71$. The statistical value for 0.05 at 71 degree of freedom is 1.99 and the calculated value $t=17.336$ is greater than the tabulated value of 1.99 therefore we accept the alternative hypothesis. (H1). This implies that there is a significant relationship between agency and poor corporate governance.

\section{Further Findings and Discussions}

The study was carried out with a view to examining the issue of agency in corporate governance. It was observed that directors and the top management act as agents to the shareholders who are the owners of the firm. These agents are expected to maximize the benefits accruing to the share holders and also consider the interest of the other stakeholders. Unfortunately, both the owners and the agents have conflicting interest. There is usually information asymmetry hence the shareholders cannot rightly determine the interest being pursued by the agents. The responsibility of the board to the stockholders of the company is to improve corporate value and performance, to ensure good growth, market capitalization as well as shareholders' value and these depend to a 
greater extent, on the board of directors, that is independently minded. However, the board of directors of these banks together with the management staff do not conform to these expected agency functions. Rather, they pursue their own selfish interest, which is usually, to the detriment of their principals, the owners of the firms.

It was observed that agency has impacted negatively on corporate governance in the Nigeria banking sector. Obviously, agency problems arise in wider dimensions. Between the agents and the principal, there is usually lack of transparency and between the agent and other stakeholders there is the problem of non-disclosure of material facts that may inform the decisions of the stakeholders. It was found out that a good number of banks conceal vital information from the regulatory authorities by rendering false/ incorrect returns. It is even worse when there is no separation between the management and the board as the executive chairmen will always have their ways through the rubber stamp board and pursue interests which run contrary to those of the stockholders and the stakeholders.

Table 12 displayed in the study depicts the extent to which the agents can go in granting naked loans to themselves and leave the shareholders with nothing to show for their investments .The magnitude of insider abuse in some of the failed banks is presented in the table below.

Table 12: Extent of Insider Loans to Selected Banks in Liquidation

\begin{tabular}{|c|l|c|c|}
\hline S/N & \multicolumn{1}{|c|}{ Bank } & $\begin{array}{l}\text { Ratio of Insider Loans to Total } \\
\text { Loans (\%) }\end{array}$ & $\begin{array}{l}\text { Ratio of Non-Performing Loans } \\
\text { to Total Loans (\%) }\end{array}$ \\
\hline 1 & Financial Merchant Bank & 66.9 & 99.5 \\
\hline 2 & Kapital Merchant Bank & 50.0 & 96.2 \\
\hline 3 & Alpha Merchant Bank & 55.0 & 90.0 \\
\hline 4 & United Commercial Bank & 81.0 & 90.0 \\
\hline 5 & Republic Bank & 64.9 & 98.0 \\
\hline 6 & Commercial Trust Bank & $55-9$ & 100.0. \\
\hline 7 & Commerce Bank & 52.0 & 86.9 \\
\hline 8 & Credite Bank & 76.0 & 98.3 \\
\hline 9 & Prime Merchant Bank & 80.7 & 100.0 \\
\hline 10 & Group Merchant Bank & 77.6 & 94.5 \\
\hline 11 & Nigeria Merchant Bank & 99.9 & 95.9 \\
\hline 12 & Royal Merchant Bank & 69.0 & 98.0 \\
\hline
\end{tabular}

Source: NDIC Annual Report (Various Years).

Another serious case in point is that of the ugly incident of poor corporate governance which engulfed the Nigerian banking sector in August, 2009 and which ultimately led to the sudden takeover of nine out of the twenty- four banks and the immediate sack of their managing and executive directors.

\section{Concluding Remarks}

The study carried out an examination of the role of agency in corporate governance. It observed the extent to which management and the board perform their agency functions. The study noted that both management and the board pursue a different interest altogether from those of the shareholders and other stakeholders. The methodology used involves the collection of primary data and putting them in a frequency table. T-test statistic was used to show the degree of association between corporate governance and agency. In the final analysis, the study saw agency as one of the devastating aspect of corporate governance because it breeds, lack of transparency, non-disclosure of material information and the granting of insider related credits. The study therefore recommends that the banking sector should endeavour to entrench effective corporate governance that will frown at executive duality, weak internal controls, abuses in lending and compel the directors and management to be truly and genuinely accountable to the stakeholders. It also recommends that the Central Bank of Nigeria should strengthen its enforcement mechanisms such that there will be total transparency and full disclosure of all material transactions to the stakeholders and the regulatory authorities.

\section{References}

Adedipe, B. (2004). Corporate governance: key factor in financial sector stability. Paper delivered at the $5^{\text {th }}$ Annual Finance Correspondents and Business Editors Seminar held in Owerri, January 26-28

Akinsulire O (2002). Financial management. Lagos: El-Toda Ventures Limited

Anameje, A.C. (2007). Banking and finance professionalism in the $21^{\text {st }}$ century and beyond. The Nigerian Banker, .October- December Edition, $14-17$ 
Caramanolis-Cotelli, B. (1995). External and internal corporate control mechanism and the role of.the board of directors: A review of the literature Working Paper No 9606.Institute of .Banking .and Financial Management

Central Bank of Nigeria (2006). Code of corporate governance for banks in Nigeria post-consolidation, March 1

Cheserem M, Bowes G, Garratt B, Gillibrand M, Jayamaha R, Laferla H.Z, Mortlock G \& Reddy Y.R.K. (2000). Corporate governance in the financial sector. Issued by the .Commonwealth .Working .Group, November.

Chukwudire, U. (2004).Corporate governance in the Nigerian financial services industry. . The Nigerian Banker, July-December, 15-20

Diplock, J. C. (2004). Why bother with better corporate governance? Speech delivered at theInstitute of Directors of New Zealand Inc. Auckland Securities Commission, New Zealand

Eisenhardt, K (1989). Agency theory: An assessment and review. Academy of Management Review, 14, 57-74

Fama, E. F. (1980). Agency problem and the theory of the firm. Journal of Political Economy. 88 (2) 288-307

Forsberg, R.(1989).Outside directors and managerial monitoring Akron Business and Economic.Review, 20, $24-$ 32

Jensen M. \& Meckling W.(1976). Theory of the firm: Managerial behavior, agency costs and ownership structure. Journal of Financial Economics 3, 305-360

John, K. \& Senbet, L.W. (1998).Corporate governance and board effectiveness Journal of Banking and Finance, $22,371-403$

Kumar S.\& Singh V.K (2010).Corporate governance: Meaning and implementation. Global Journal of Finance and Management, 2 (2), 197-207

Macey J.R.(2008).Corporate governance of banks Princeton and London, Princeton: University Press 2

Macey J.R.\& O'Hara M (2003).The corporate governance of banks. FRBNY Economic Policy Review, April,

Mayer, R.C, Davis J. H.\& Schoorman F.D. (1995). An integrative model of organizational trust. Academy of Management .Review, 20, (3) 709-734

Monks, R. A. \& Minow N (1995). Corporate governance, Cambridge: M A Blackwell

Mulbert P.O.(2009). Corporate governance of banks: European Business Organization. Law Review, 10: 411-436

Oluyemi, S. A. (1995): Banking sector reforms and the imperatives of good corporate governance in the Nigerian banking system. NDIC Quarterly, 16, (1), 72-101

Owoh, G U (2006).Corporate governance in a private- led economy: Balancing the issues. The Nigerian Banker, July -September, 7-17

Peterson D.K.(2010).Agency perspectives on NGO governance. Journal of Management Research, 2(2)1-11

Ross, S. (1973) The economic theory of agency: "The principal's problem" American Economic Review 63 (2) 134-139

Sanusi, J. O. (2002) Enhancing good corporate governance: A strategy for financial sectorsoundness. A keynote address delivered at the Annual Dinner of the Chartered Institute of Bankers, at Abuja, Nigeria on November 8

Sanusi, J. O. (2003): Embracing good corporate governance practice in Nigeria. Paper delivered at a.Seminar organized by the Financial Institutions Training Centre, Abuja, Nigeria

Sanusi, J.O. (2004). Corporate Governance: A keynote address delivered at Abuja between February $17-20$

Shleifer, A., \& Vishny R. W. (1997): A survey of corporate governance. Journal of Finance 52, (2), 737-783

Tricker, R. I. (1994): International corporate governance: Singapore, Simon and Schuster

Van Horne, J. C.(2002). Financial management and policy. India, Pearson Education

Zingales, L. (1998) Corporate governance. In P. Newman ( Ed) The New Palgrave Dictionary of Economics and the Law. London, Macmillan 497-502 
The IISTE is a pioneer in the Open-Access hosting service and academic event management. The aim of the firm is Accelerating Global Knowledge Sharing.

More information about the firm can be found on the homepage:

http://www.iiste.org

\section{CALL FOR JOURNAL PAPERS}

There are more than 30 peer-reviewed academic journals hosted under the hosting platform.

Prospective authors of journals can find the submission instruction on the following page: http://www.iiste.org/journals/ All the journals articles are available online to the readers all over the world without financial, legal, or technical barriers other than those inseparable from gaining access to the internet itself. Paper version of the journals is also available upon request of readers and authors.

\section{MORE RESOURCES}

Book publication information: http://www.iiste.org/book/

\section{IISTE Knowledge Sharing Partners}

EBSCO, Index Copernicus, Ulrich's Periodicals Directory, JournalTOCS, PKP Open Archives Harvester, Bielefeld Academic Search Engine, Elektronische Zeitschriftenbibliothek EZB, Open J-Gate, OCLC WorldCat, Universe Digtial Library, NewJour, Google Scholar

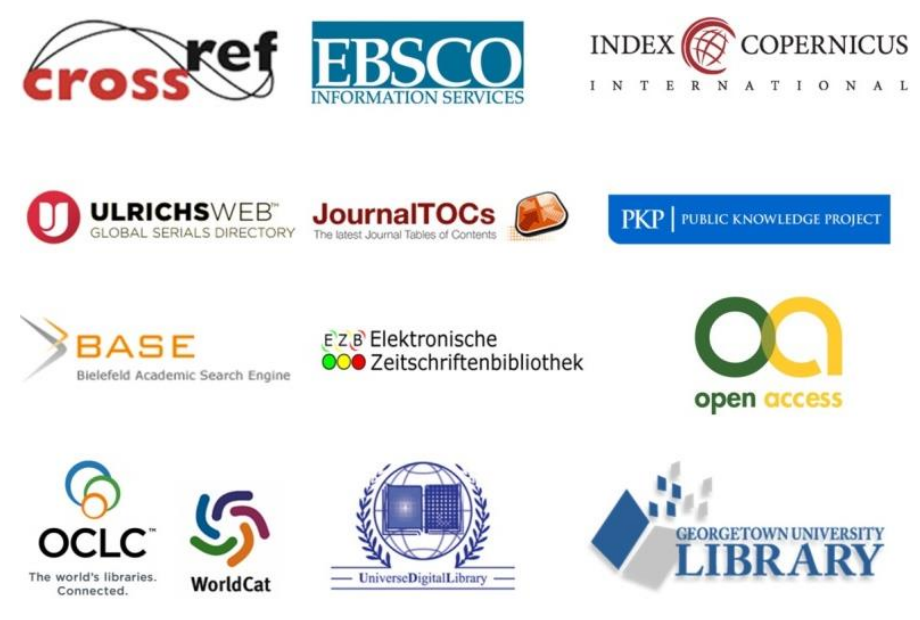

